\title{
Adoptive immunotherapy with MUC1-mRNA transfected dendritic cells and cytotoxic lymphocytes plus gemcitabine for unresectable pancreatic cancer
}

Yoshitaro Shindo' ${ }^{1}$ Shoichi Hazama', Yoshinari Maeda', Hiroto Matsui ${ }^{1}$, Michihisa lida', Nobuaki Suzuki', Kiyoshi Yoshimura', Tomio Ueno ${ }^{1}$, Shigefumi Yoshino ${ }^{1}$, Kohei Sakai ${ }^{2}$, Yutaka Suehiro², Takahiro Yamasaki ${ }^{2}$, Yuji Hinoda ${ }^{2}$ and Masaaki Oka ${ }^{1 *}$

\begin{abstract}
Background: We previously reported the clinical efficacy of adoptive immunotherapy (AIT) with dendritic cells (DCs) pulsed with mucin 1 (MUC1) peptide and cytotoxic T lymphocytes (CTLs). We also reported that gemcitabine (GEM) enhances anti-tumor immunity by suppressing regulatory $T$ cells. Therefore, in the present study, we performed combination therapy with AIT and GEM for patients with unresectable or recurrent pancreatic cancer.

Patients and methods: Forty-two patients with unresectable or recurrent pancreatic cancer were treated. DCs were generated by culture with granulocyte macrophage colony-stimulating factor and interleukin-4 and then exposed to tumor necrosis factor-a. Mature DCs were transfected with MUC1-mRNA by electroporation (MUC1-DCS). MUC1-CTLs were induced by co-culture with YPK-1, a human pancreatic cancer cell line, and then with interleukin-2. Patients were treated with GEM, while MUC1-DCs were intradermally injected, and MUC1-CTLs were intravenously administered.
\end{abstract}

Results: Median survival time (MST) was 13.9 months, and the 1-year survival rate was 51.1\%. Of 42 patients, one patient had complete response (2.4\%), three patients had partial response (7.1\%) and 22 patients had stable disease (52.4\%). The disease control ratio was 61.9\%. The MST and 1-year survival rate of 35 patients who received more than $1 \times 10^{7}$ MUC1-DCs per injection was 16.1 months and $60.3 \%$, respectively. Liver metastasis occurred in only 5 patients among 35 patients without liver metastasis before treatment. There were no severe toxicities associated with AIT.

Conclusion: AIT with MUC1-DCs and MUC1-CTLs plus GEM may be a feasible and effective treatment for pancreatic cancer.

Keywords: Pancreatic cancer, MUC1, Dendritic cell, Cytotoxic lymphocyte, Gemcitabine, Immunotherapy

\footnotetext{
* Correspondence: moka@yamaguchi-u.ac.jp

'Department of Digestive Surgery and Surgical Oncology (Department of

Surgery II), Yamaguchi University Graduate School of Medicine, 1-1-1

Minami-kogushi, Ube, Yamaguchi 755-8505, Japan

Full list of author information is available at the end of the article
} 


\section{Background}

Pancreatic adenocarcinoma is the fourth leading cause of cancer death worldwide and has an overall 5-year survival rate of only $6 \%$ [1]. No adequate therapy for pancreatic cancer has yet been found, and most patients die within a year of diagnosis. New treatment strategies are therefore necessary.

Immunotherapy has an advantage over radiation and chemotherapies because it can act specifically against the tumor without damaging normal tissue. Immunotherapeutic approaches to pancreatic cancer have included the use of monoclonal antibodies (mAbs) [2], cytokines [3], vaccines [4], and lymphokine-activated killer (LAK) cells [5]. Dendritic cells (DCs) play important roles as antigen-presenting cells in innate and adaptive immunity [6]. DC-based therapy has been used in clinical trials for various cancers including pancreatic cancer [7-9].

Mucin 1 (MUC1) is overexpressed in an incompletely glycosylated form in various human cancers [10]. We have previously reported that the expression of MUC1 was observed in all cancer cells from all 55 pancreatic ductal adenocarcinomas as well as 2 liver metastases by immunohistochemistry. In contrast the expression of MUC1 was not observed in specimens from normal pancreas, chronic pancreatitis, or ductal hyperplasia of the pancreas [11]. Cytotoxic $\mathrm{T}$ lymphocytes (CTLs) recognize MUC1 molecules in a human leukocyte antigen (HLA)-unrestricted manner, which means that these cells can be used for all cancer patients such as pancreatic, breast, or ovarian cancer expressing MUC1 antigen [12-16]. We have previously reported adoptive immunotherapy (AIT) with CTLs stimulated by a MUC1-expressing human pancreatic cancer cell line, YPK-1, (MUC1-CTLs) for unresectable pancreatic cancer [15]. We have also reported the efficacy of AIT with MUC1 peptide-pulsed DCs and MUC1-CTLs [16].

DCs are potent antigen-presenting cells for induction of primary T-cell dependent immune responses [6]. Numerous studies have demonstrated the feasibility of DC-based immunization to induce host responses against tumors [17]. DCs can be pulsed with peptide [16], fulllength protein [18], or whole tumor cells [19], and transfected with DNA or RNA $[20,21]$ or transduced with recombinant viruses [22]. Comparative studies suggest that mRNA transfection may be superior to other antigen-loading techniques in generating immunocompetent DCs [23].

Gemcitabine (GEM), which is a standard chemotherapeutic agent for pancreatic cancer [24], is not immunosuppressive and may enhance responses to specific vaccines or immunotherapy administered to activate or support immune responses directed toward driving effector immunity to cancer cells $[24,25]$. Treatment with GEM sensitizes human pancreatic carcinoma cell lines against CTL-mediated lysis [26]. DC-based vaccination combined with GEM increases survival in a murine pancreatic carcinoma model [27].

To create a more effective therapy for pancreatic cancer, we conducted combined AIT with MUC1-CTLs and MUC1-mRNA-transfected dendritic cells (MUC1-DCs) plus GEM.

\section{Patients and methods}

\section{Patients and eligibility criteria}

Between 2007 and 2012, 42 patients with unresectable or recurrent pancreatic cancer histologically confirmed as invasive ductal carcinoma by endoscopic ultrasound-guided fine-needle aspiration were treated at the Department of Digestive Surgery and Surgical Oncology (Department of Surgery II) of the Yamaguchi University Graduate School of Medicine. This therapy was not a clinical trial, but a medical treatment approved as advanced health care by the Japanese Ministry of Health, Labor and Welfare, and provided for all patients who could pay the cost for this therapy and who met the basic criteria as described below. We retrospectively summarized safety and efficacy of this therapy. The study protocol was also approved by the Institutional Review Board for Human Use at the Yamaguchi University School of Medicine. Written informed consent was obtained from all patients.

Eligibility criteria were as follows: age of $\geq 20$ years; life expectancy $\geq 3$ months; and adequate hepatic, renal, and bone marrow function (serum creatinine level, $<2.0 \mathrm{mg} / \mathrm{dl}$; bilirubin level, $<3.0 \mathrm{~g} / \mathrm{dl}$; platelet count, $\geq 75,000 / \mathrm{ml}$; total white blood cell count $\geq 3,000 / \mathrm{ml}$ and $\leq 15,000 / \mathrm{ml}$ ). All patients had to have an Eastern Cooperative Oncology Group (ECOG) performance status (PS) of 0-2 at the time of initial consultation.

\section{Treatment protocol}

Patients were treated with GEM $\left(1000 \mathrm{mg} / \mathrm{m}^{2}\right)$ for 3 weeks (on days 1, 8, and 15) followed by 1 week of rest, while MUC1-DCs suspended in $2 \mathrm{ml}$ saline were injected intradermally in the inguinal region as maximum available cell products, and MUC1-CTLs suspended in $100 \mathrm{ml}$ saline were given intravenously as maximum available cell products on day 18 every 4 weeks (Figure 1a). This AIT was repeated until progressive disease (PD) was recognized.

\section{Adverse events and clinical responses}

Adverse events were evaluated according to the Common Terminology Criteria for Adverse Events v3.0 (CTCAE) [28]. Computed tomography (CT) scan or magnetic resonance imaging (MRI) examination was made before the treatment. Tumors were staged with the UICC classification system.

CT or MRI was made after the first 3 transfers and was repeated every 4 to 6 weeks after the treatment. Patients 


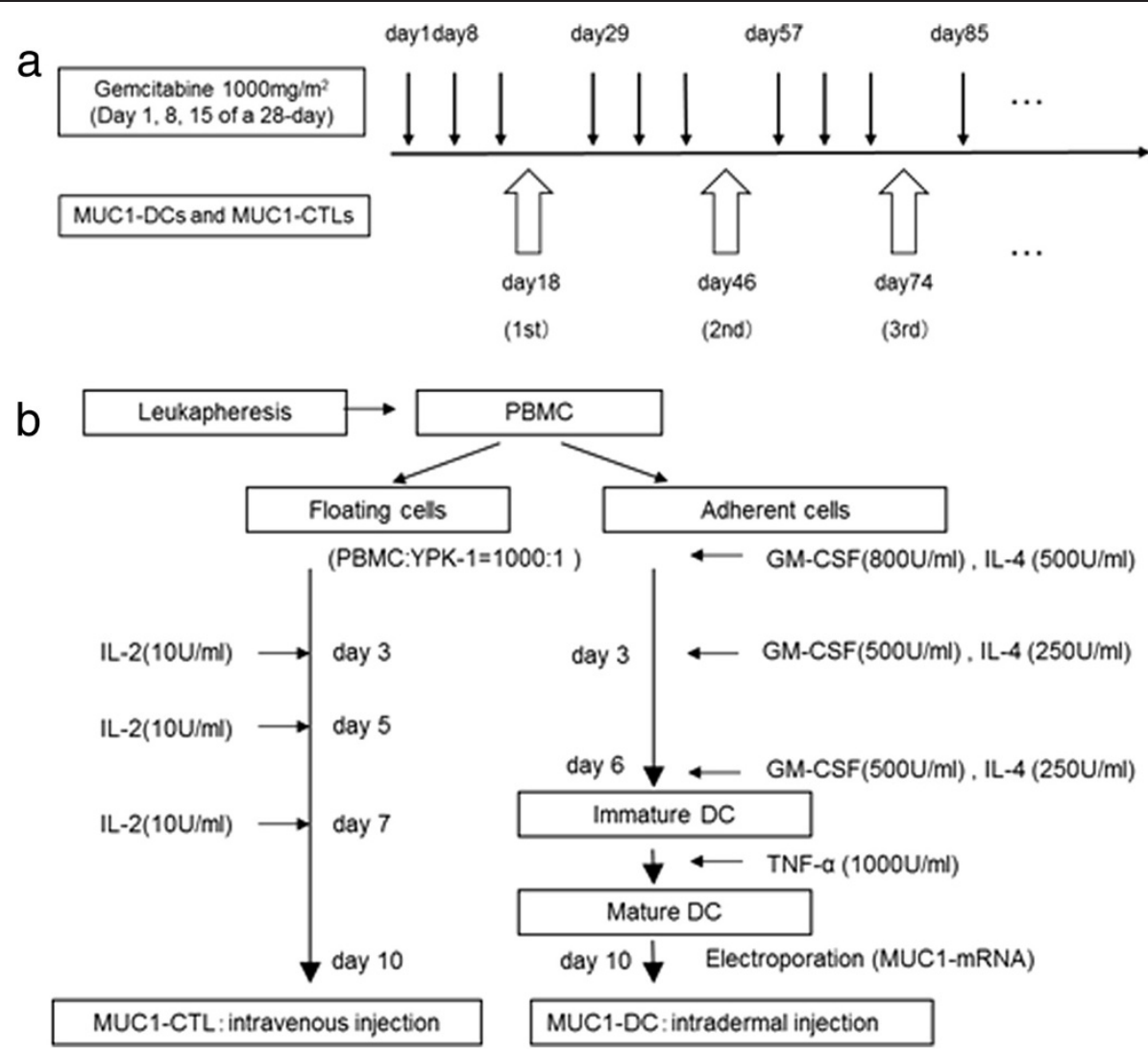

Figure 1 Treatment regimen. a; Patients were treated with GEM $\left(1000 \mathrm{mg} / \mathrm{m}^{2}\right)$ for 3 weeks (on days 1, 8, and 15) followed by 1 week of rest, while MUC1-DCs and MUC1-CTLs were administrated on day 18 every 4 weeks. b; MUC1-CTLs were induced by co-culture with YPK-1, a human pancreatic cancer cell line, and then with IL-2. DCs were generated by culture with GM-CSF and IL-4 and then exposed to TNF-a. Mature DCs were transfected with MUC1-mRNA by electroporation (MUC1-DCs).

were assigned a response category according to the Response Evaluation Criteria in Solid Tumors (RECIST) Committee [29].

\section{Generation of MUC1-mRNA}

MUC1-mRNA was transcribed in vitro. An XhoI fragment containing a full length of MUC1 cDNA was cloned into the Xhol site of the pcDNA3.1. Clones containing the MUC1 cDNA were isolated, and midi scale cDNA preparations were generated using Quantum Prep ${ }^{\mathrm{Tm}}$ Plasmid Midiprep Kit (Bio Rad, Hercules, CA, USA). The plasmid vector was linearized with $X h o I$ digest and purified with Wizard SV Gel and PCR Clean-Up System (Promega, Madison, Wisc., USA). In vitro transcription was then carried out using a mMessage mMachine ${ }^{\bullet}$ T7 Ultra Kit (Ambion, Austin, Tex., USA) according to the manufacturer's protocol.

\section{Separation of adherent and non-adherent cells}

Peripheral blood mononuclear cells (PBMCs) were harvested with the COBE Spectra Apheresis System (COBE BCT, Inc., Lakewood, CO, USA). PBMCs from
$3000 \mathrm{ml}$ of blood were enriched by density gradient centrifugation with Ficoll-Paque (Amersham Pharmacia Biotech, Uppsala, Sweden). The PBMCs were incubated for $45 \mathrm{~min}$ in a $5 \% \mathrm{CO}_{2}$ atmosphere at $37^{\circ} \mathrm{C}$ in serum-free AIM-V medium (Gibco, Paisley, Scotland). Plastic-adherent cells were used for the generation of DCs, while nonadherent cells were used for the generation of CTLs.

\section{Generation of MUC1-CTLs}

MUC1-CTLs were induced as previously described [15]. Briefly, non-adherent cells were cultured in AIM-V with the MUC1-expressing human pancreatic cancer cell line YPK-1 (HLA-A2402) inactivated with $0.2 \mathrm{mg} / \mathrm{ml}$ mitomycin C (Kyowa Hakko Kogyo Co., Ltd., Tokyo, Japan). The effector-to-stimulator cell ratio was 1,000:1. On days 3, 5, and 7, recombinant human interleukin 2 (IL-2) (Shionogi Pharmaceutical Co., Tokyo, Japan) was added to the cultures at a final concentration of 10 units $/ \mathrm{ml}(\mathrm{U} / \mathrm{ml})$. The plates were incubated in a $5 \% \mathrm{CO}_{2}$ atmosphere at $37^{\circ} \mathrm{C}$. On day 10, MUC1-CTLs were washed 3 times with saline, suspended in $100 \mathrm{ml}$ saline and administered intravenously (Figure 1b). 


\section{Cytotoxicity assay and antibody inhibition assay of cytotoxicity}

Cytotoxicity assays of MUC1-CTLs induced from a healthy volunteer with the HLA-A 24/26 were performed as previously described (Additional file 1: Figure S1a) [15]. Briefly, target cells $\left(1 \times 10^{6} / \mathrm{ml}\right)$ were labeled for $60 \mathrm{~min}$ at $37^{\circ} \mathrm{C}$ with $100 \mu \mathrm{Ci} / \mathrm{ml}$ radioactive sodium chromate $\left({ }^{51} \mathrm{Cr}\right)$ (Amersham Japan, Tokyo, Japan). The cells were then washed 4 times in RPMI-1640 medium (Sigma-Aldrich). Labeled cells were resuspended in culture medium $\left(1 \times 10^{5} / \mathrm{ml}\right)$. Effector cells consisting of induced MUC1CTLs were suspended at $0.5,1.0$ or $2.0 \times 10^{6} / \mathrm{ml}$. Effector cell suspension $(0.1 \mathrm{ml})$ was added to a microplate (Falcon Plastics, Cockeysville, MD) with $0.1 \mathrm{ml}$ target cells, to yield an effector to target cell ratio of $5: 1,10: 1$ or 20:1. All experiments were performed in triplicate. Plates were incubated for $4 \mathrm{~h}$ at $37^{\circ} \mathrm{C}$ in a $\mathrm{CO}_{2}$ incubator. The amount of ${ }^{51} \mathrm{Cr}$ released into each well was determined with a $\gamma$ counter (Auto Well Gamma System ARC-202, Aloka, Tokyo, Japan). The percentage of cytotoxicity was calculated as follows:

$$
\% \text { cytotoxicity }=\frac{\text { experimental release }- \text { spontaneous release }}{\text { maximum release }- \text { spontaneous release }}
$$

To measure the spontaneous ${ }^{51} \mathrm{Cr}$ release of target cells in the absence of effector cells, target cells were mixed with $0.1 \mathrm{ml}$ culture medium. To obtain maximal a ${ }^{51} \mathrm{Cr}$ release, target cells were treated with $0.1 \mathrm{ml}$ $0.1 \mathrm{~N}$ hydrochloric acid [15].

Antibody inhibition assay of cytotoxicity of induced MUC1-CTLs induced from a healthy volunteer with the HLA-A 24/26 was described previously (Additional file 1: Figure S1b) [15]. Briefly, anti-CD3, -CD4, -CD8 and anticlass I mAbs (each diluted at 1:50) were used for blocking assays and were purchased from Dako Corp., Carpinteria, CA. The MUC1-expressing pancreatic cancer cell line YPK-1 was used as the target cell. Effector cells consisting of induced MUC1-CTLs were incubated with mAb at the indicated concentrations for $45 \mathrm{~min}$ at $37^{\circ} \mathrm{C}$, washed 3 times in RPMI-1640 medium and suspended at $2 \times 10^{6} / \mathrm{ml}$. Target cells were labeled with ${ }^{51} \mathrm{Cr}$ as described above, washed 4 times and resuspended in culture medium $\left(1 \times 10^{5} / \mathrm{ml}\right)$. Effector cell suspension $(0.1 \mathrm{ml})$ was added with $0.1 \mathrm{ml}$ target cells to yield a 20:1 effector to target cell ratio for cytotoxicity assays as described above. For anti-MUC1 mAb blocking, target cells were preincubated for $1 \mathrm{~h}$ at $37^{\circ} \mathrm{C}$ with anti-MUC1 mAb MY.1E12 (diluted at 1:200), kindly provided by Dr Tatsuo Irimura, Department of Cancer Biology and Molecular Immunology, Faculty of Pharmaceutical Sciences, University of Tokyo, Japan. Cytotoxicity assays were performed as described above [15].

\section{Generation of MUC1-DCs}

Adherent cells were cultured in AIM-V medium containing $800 \mathrm{U} / \mathrm{ml}$ granulocyte macrophage colony-stimulating factor (GM-CSF) (Osteogenetics $\mathrm{GmbH}$, Wurzburg, Germany) and $500 \mathrm{U} / \mathrm{ml}$ IL-4 (Osteogenetics $\mathrm{GmbH}$ ). On days 3 and 6, GM-CSF and IL-4 were added to the cultures at a final concentration of $400 \mathrm{U} / \mathrm{ml}$ and 250 $\mathrm{U} / \mathrm{ml}$ respectively. On day 6 , immature DCs (imDCs) were cultured in AIM-V medium containing $1000 \mathrm{U} / \mathrm{ml}$ tumor necrosis factor- $\alpha$ (TNF- $\alpha)$ (R\&D Systems, Minneapolis, MN, USA). On day 10, floating and loosely adherent cells were collected as mature DCs (mDCs). The $\mathrm{mDCs}$ were washed once, suspended in AIM-V medium, and adjusted to a final cell density of $2 \times 10^{6}$ cells $/ \mathrm{ml}$. Subsequently, $400 \mu \mathrm{l}$ of the cell suspension was mixed with $10 \mu \mathrm{g}$ of MUC1-mRNA and electroporated in a 4-mm cuvette by using a BTX 830 square-wave electroporator (Harvard Apparatus, Holliston, MA, USA). Electroporation settings were adjusted to a single pulse, $400 \mathrm{~V}, 500 \mu \mathrm{s}$. Subsequently, MUC1-DCs were washed 3 times with saline, suspended in $2 \mathrm{ml}$ saline and injected intradermally in the inguinal region (Figure 1b).

\section{Enhanced green fluorescent protein (EGFP) expression on mDCs by flow cytometry}

EGFP mRNA electroporated DCs were checked for EGFP expression $18 \mathrm{~h}$ after transfection by an EPICS Flow Cytometer. Gating was performed on cells exhibiting a large forward scatter (FSC) and side scatter (SSC) profile in order to allow exclusion of contaminating autologous lymphocytes. Gated DCs were then evaluated for EGFP expression. Non-transfected DCs were used as a control.

\section{Analysis of DC subsets}

Induced DC subsets were analyzed with mAbs against surface antigens. All mAbs were purchased from Coulter (Hialeah, FL, USA). FITC-conjugated anti-CD80 (B7-1), CD83 (HB-15), -CD14 (B1), -HLA-ABC and -HLA-DR (I2) were used. PE-conjugated anti-CD86 (B7-2) and -CD40 were also used according to the manufacturer's instructions. Samples were analyzed with an EPICS Flow Cytometer (Coulter Electronics, Inc., Hialeah, FL, USA) at a fluorescence excitation wavelength of $488 \mathrm{~nm}$ at $200-500 \mathrm{~mW}$. For each sample, 5,000 DCs were analyzed.

\section{Analyses of Myeloid-derived suppressor cell (MDSC) and regulatory $\mathrm{T}$ cell (Treg) in PBMCs}

PBMCs (obtained before the treatment and one month after 3 transfers) were enriched by density gradient centrifugation with Ficoll-Paque (Amersham Pharmacia Biotech, Uppsala, Sweden). Cells were aliquoted for MDSC and Treg analysis. Cells were incubated with energycoupled dye-phycoerythrin-Texas Red (ECD)- conjugated 
anti-human CD4 (T4), FITC-conjugated anti-human CD25 (Beckman Coulter), VioBlue-conjugated anti-human CD11b (M1/70.15.11.5) (Miltenyi Biotech, Bergisch Gladbach, Germany), FITC-conjugated anti-human CD33 (HIM3-4) (eBioscience, San Diego, CA, USA) or the corresponding isotype control Abs (Beckman Coulter) for $30 \mathrm{~min}$ at $4^{\circ} \mathrm{C}$. For Treg intra-nuclear Foxp3 analysis, after treatment with rat serum and permeabilization buffer for $15 \mathrm{~min}$ at $4^{\circ} \mathrm{C}$, cells were incubated with rat PE-labeled human Foxp3 Ab (PCH101) (eBioscience, San Diego, CA, USA) or the appropriate isotype control (Beckman Coulter) for $30 \mathrm{~min}$ at $4^{\circ} \mathrm{C}$, then washed, re-suspended in $1 \%$ paraformaldehyde (PFA) in Dulbecco's phosphatebuffered saline (D-PBS) (Nissui pharmaceutical, Tokyo, Japan), and stored at $4^{\circ} \mathrm{C}$ in the dark until flow cytometric analysis. Two-color flow cytometry was performed with an EPICS flow cytometer (Coulter Electronics, Inc., Hialeah, FL). Treg analysis was performed using at least 30,000 cells that were gated in the region of the lymphocyte population, whereas for MDSC analysis, all cells including the region of mononuclear cells and the polymorphonuclear leukocyte population were analyzed. Lymphocytes were gated in FSC and SSC profiles. Tregs were identified as CD4 + CD25+ Foxp3+ and calculated as a percentage of $\mathrm{CD} 4+$ lymphocytes. MDSCs were identified as $\mathrm{CD} 11 \mathrm{~b}+\mathrm{CD} 33+[30]$ and calculated as a percentage of total PBMC.

\section{Enzyme-linked immunoSpot (ELISPOT) assay}

Frozen PBMCs, obtained before the treatment, after first treatment and after third treatment, were thawed prior to use and rested overnight in $10 \mathrm{U} / \mathrm{ml}$ benzonase nuclease (Novagen) at $37^{\circ} \mathrm{C} 5 \% \mathrm{CO}_{2}$ in a humidified incubator, and then used in the next step. PBMCs (responder cells) were cultured with the MUC1-mRNA electroporated PBMCs (stimulator cells) at the responder cells to stimulator cells $(\mathrm{R} / \mathrm{S}$ ratio) of $1: 1$, and then were measured for interferon- $\gamma$ (IFN- $\gamma)$ responses using ex vivo ELISPOT assay. Nitrocellulose bottomed 96-well Multiscreen plates (Millipore, UK Ltd) were coated with anti-human-IFN- $\gamma$ $\mathrm{mAb}$ (Mabtech, UK) overnight at $4^{\circ} \mathrm{C}$. PBMCs were plated in $100 \mu \mathrm{l}$ final volume and plates were incubated for $18-20 \mathrm{~h}$ in a $5 \% \mathrm{CO}_{2}$ atmosphere at $37^{\circ} \mathrm{C}$. Assays were performed in triplicate and the results were averaged. Plates were washed and developed. Number of spots on the plate was counted by Eliphoto Scan (Minerva Tech, Tokyo, Japan). MUC1 specific spots of IFN- $\gamma$ were counted and calculated as described below.

$$
\begin{aligned}
\text { MUC1 specific spots }= & (\text { Number of spots from } A) \\
& -(\text { Number of spots from } B)
\end{aligned}
$$

A; PBMCs co-cultured with PBMCs electroporated with MUC1 mRNA
B; PBMCs co-cultured with PBMCs electroporated without mRNA

\section{Evaluation of DC migration}

Indium oxine ( ${ }^{111}$ In-Oxine) labeled DC study was performed in one patient with stable disease (SD). DCs were labeled according to the protocols supplied by the manufacturer (Nihon Medi-Physics, Hyogo, Japan). Mature-DCs were resuspended in platelet-poor autologous plasma (CFP1) and incubated for $15 \mathrm{~min}$ at room temperature with radioactive ${ }^{111}$ In-Oxine $(1 \mathrm{mCi})$ (Nyconmed Amersham Inc., Buckinghamshire, UK). After two washes to eliminate the unbound isotope, the cells were resuspended in a total volume of $1.5 \mathrm{ml}$ of CFP1. Radiolabelling of the DCs and culture supernatant was evaluated with a gamma camera, after which DCs were intradermally inoculated $10 \mathrm{~cm}$ from inguinal lymph nodes. Scintigraphic images of the depot were acquired with a gamma camera $0,2,24$, and $48 \mathrm{~h}$ after injection.

\section{Statistical analysis}

Results are expressed as means \pm standard error (SE). All data were analyzed by using GraphPad Prism V5.0 (GraphPad Software, Inc., San Diego, CA). Changes in surface markers were assessed with the paired Student's $t$ test. Survival curves were analyzed by the Kaplan-Meier method and the log-rank test. Categorical variables were compared by using Chi-square and Fisher's exact test. P-values $<0.05$ were considered statistically significant.

\section{Results}

\section{Clinical outcomes}

Patient characteristics and clinical outcomes are summarized in Table 1 . Of 42 patients receiving AIT with MUC1-DCs and MUC1-CTLs plus GEM, 1 patient with recurrence had complete response (CR) (2.4\%), 3 patients with stage III $(\mathrm{n}=1)$ and stage IV $(\mathrm{n}=2)$ had partial response (PR) (7.1\%), 22 patients with stage III $(\mathrm{n}=11)$, stage IV $(n=7)$ and recurrence $(n=4)$ had SD $(52.4 \%)$, and 16 patients with stage III $(\mathrm{n}=2)$, stage IV $(\mathrm{n}=10)$ and recurrence $(\mathrm{n}=4)$ had PD $(38.1 \%)$. The disease control rate was $61.9 \%$.

Images from gadolinium ethoxybenzyl diethylenetriamine pentaacetic acid-enhanced (Gd-EOB-DTPA) MRI and CT scans of a patient with CR are shown in Figure 2. He had liver metastasis after curative surgery (Figure 2a and b). After 3 transfers, liver metastasis disappeared completely (Figure 2c and d). In contrast, the other 6 patients who had liver metastasis before this therapy had PD and the median survival time (MST) was 6.3 months (data not shown).

The 1-year survival rate was $51.1 \%$, and the MST was 13.9 months in all patients (Figure 3a). Liver metastasis during therapy appeared in only 5 of 35 patients without 


\section{Table 1 Patient characteristics and clinical outcomes}

Number of patients

$\begin{array}{lc}\text { Age (years) } & 63.1 \\ \text { Mean } & 37-81 \\ \text { Range } & \\ \text { Sex } & 21 \\ \text { Males } & 21 \\ \text { Females } & \\ \text { Stage } & 14 \\ \text { III } & 19 \\ \text { IV } & 9 \\ \text { Recurrence } & \\ \text { Liver metastasis (pretreatment) } & 35 \\ \text { Absence } & 7 \\ \text { Presence } & \end{array}$

HLA-A24 24

Others $\quad 17$

Unknown

Administration (times)

$<3$

$\geqq 3$

Number of CTLs $\left(\times 10^{8} /\right.$ time $)$

Mean

Range

Number of DCs $\left(\times 10^{7} /\right.$ time $)$

Mean

Range

Prior therapy

None

Tumor resection

Chemotherapy

Radiotherapy

Response

$C R$

$P R$

SD

PD

42

63.1

37-81

21

21

HLA; human leukocyte antigen, CTL; cytotoxic T lymphocyte,DC; dendritic cell, $\mathrm{CR}$; complete response, $\mathrm{PR}$; partial response, $\mathrm{SD}$; stable disease, $\mathrm{PD}$; progressive disease.

liver metastasis before treatment. The 1-year survival rate and MST in 35 patients who received more than $1 \times 10^{7}$ MUC1-DCs per injection were significantly better than for 7 patients who received less than $1 \times 10^{7}$ cells $(60.3 \%$ vs. $0 \%, 16.1$ months vs. 6.2 months, $\mathrm{p}=0.0036)$ (Figure $3 \mathrm{~b}$ ). Administration times and total number of
MUC1-CTLs and MUC1-DCs were $6.2 \pm 0.8$ times, $4.5 \pm$ $0.7 \times 10^{9}$ cells and $12.9 \pm 1.8 \times 10^{7}$ cells in the high dose group, and $3.1 \pm 0.2$ times, $1.5 \pm 0.2 \times 10^{9}$ cells and $1.9 \pm$ $0.5 \times 10^{7}$ cells in the low dose group. The 1-year survival rate and MST in 36 patients who received more than $3 \times 10^{8}$ MUC1-CTLs per injection were significantly better than for 6 patients who received less than $3 \times 10^{8}$ cells $(56.6 \%$ vs. $16.7 \%, 15.1$ months vs. 5.2 months, $\mathrm{p}=$ 0.0060) (Figure 3c). Administration times and total number of MUC1-CTLs and MUC1-DCs were $6.3 \pm 0.8$ times, $4.6 \pm 0.7 \times 10^{9}$ cells and $12.4 \pm 1.8 \times 10^{7}$ cells in the high dose group, and $2.3 \pm 0.3$ times, $0.5 \pm 0.1 \times 10^{9}$ cells and $2.4 \pm 0.5 \times 10^{7}$ cells in the low dose group. The 1-year survival rate and MST in 30 patients who received both more than $1 \times 10^{7}$ MUC1-DCs per injection and $3 \times 10^{8}$ MUC1CTLs per injection were significantly better than for the other 12 patients $(66.7 \%$ vs. $10.4 \%, 16.5$ months vs. 5.7 months, $\mathrm{p}=0.0002$ ) (Figure 3d). Administration times and total number of MUC1-CTLs and MUC1-DCs were $6.8 \pm 0.9$ times, $5.0 \pm 0.8 \times 10^{9}$ cells and $14.4 \pm 2.0 \times 10^{7}$ cells in the high dose group, and $2.9 \pm 0.3$ times, $1.3 \pm$ $0.3 \times 10^{9}$ cells and $2.5 \pm 0.5 \times 10^{7}$ cells in the low dose group. There was no significant bias of patient characteristics between the high dose group and low dose group (Table 2).

A comparative analysis revealed that there were no significant differences between the clinically good (CR/PR/SD) and poor responders (PD) for age, sex, disease stage and neutrophil/lymphocyte ratio, except for pretreatment liver metastasis $(\mathrm{p}=0.0081)$ and the number of DCs $(p=0.0015)$. The number of CTLs per injection was trend to higher in the clinically good responders $(\mathrm{p}=0.0537)$ (Table 3).

\section{Safety and toxicity}

The major grade 3 and 4 adverse events are summarized in Table 4. The most common grade 3or 4 hematologic adverse event was neutrophils (31\%). Grade 3 or 4 anorexia (14.3\%) was the most nonhematologic adverse event. No AIT-related adverse events such as rash, fever, chill, and injection site reaction were observed. There was no clinical or radiological evidence of autoimmune reaction in any of the patients.

\section{Cytotoxic activity of induced MUC1-CTLs and antibody inhibition of cytotoxicity}

Induced MUC1-CTLs (HLA-A24/26) showed strong cytotoxicity against pancreatic cancer cell lines (YPK-1; HLA-A24, and YPK-3; HLA-A02) which expressed MUC1 antigen on the cell surface in an HLA- unrestricted manner. However, cytotoxicity against the esophageal cancer cell lines (YES-1 and -2), which did not express MUC1, was low (Additional file 1: Figure S1a). 

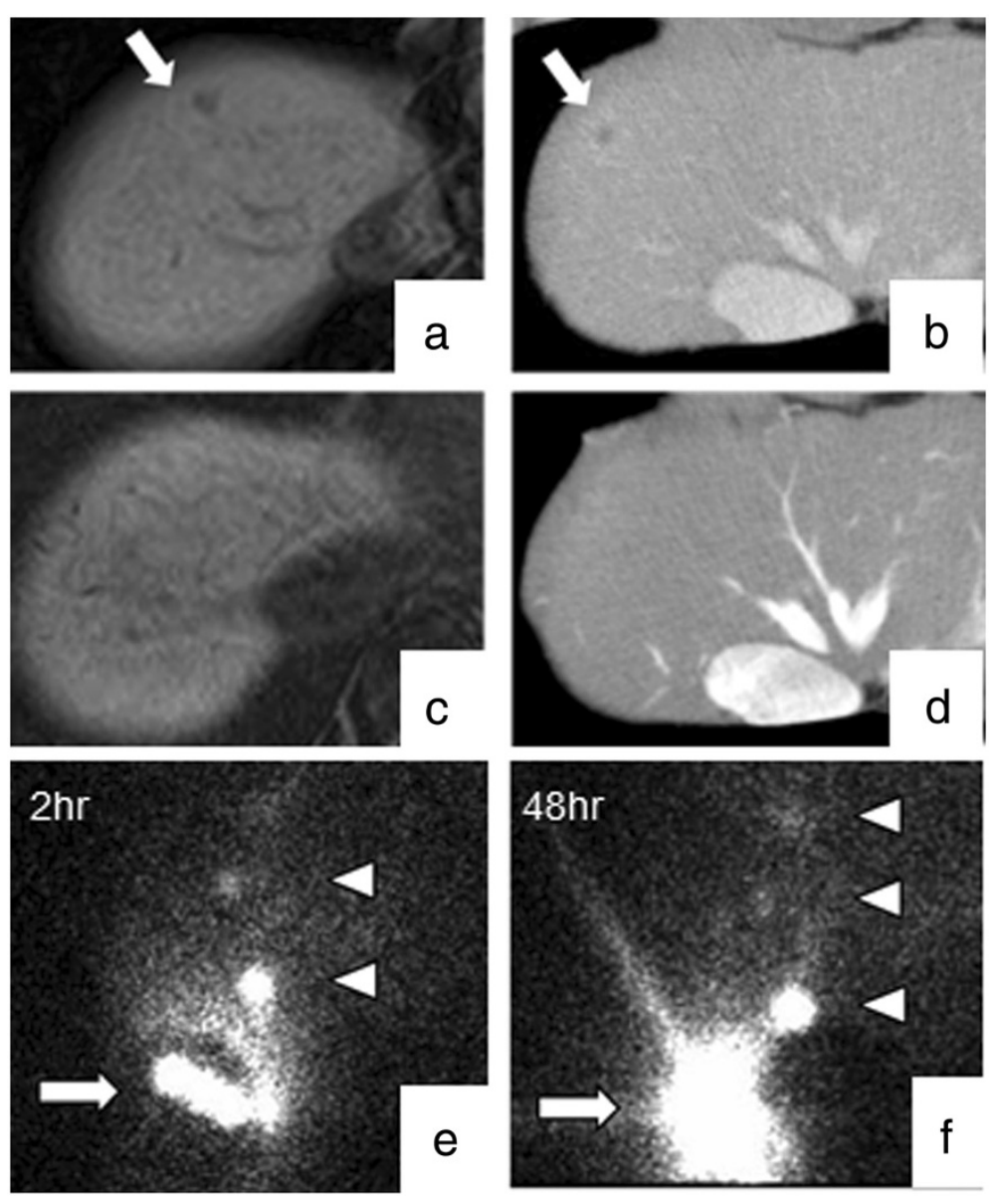

Figure 2 MRI (Gd-EOB-DTPA MRI, hepatobiliary phase) and CT scans of a patient with CR. Monitoring of in vivo migration of

${ }^{111}$ In-oxine labeled dendritic cells with scintigraphy. MRI and CT scans revealed a liver metastatic lesion (arrow) (a, b). After 3 cell transfers, the metastatic lesion disappeared completely $(\mathbf{c}, \mathbf{d})$. (a, $\mathbf{c})$ : MRI. (b,d): CT. Two hours after injection, DCs migrated from the injection site to inguinal lymph nodes (arrowhead) (e). Forty-eight hours after injection, that accumulation extended into distant lymph node, but still remained in the injection site (arrow) and inguinal lymph nodes (f).

Anti-CD3 mAb or anti-CD8 mAb inhibited CTL cytotoxicity against YPK-1 cells. Anti-MUC1 mAb also inhibited cytotoxicity in these cells. Anti-class I mAb showed no inhibition of CTL cytotoxicity $(\mathrm{E}: \mathrm{T}=20: 1$; anti-CD3, 66.5\%; -CD4, 26.9\%; -CD8, 76.9\%; anti-class I, 11.8\% and anti-MUC1, 64.1\%) (Additional file 1: Figure S1b) [15]. These results showed that cytotoxicity of induced MUC1CTLs was MUC1 specific and HLA-unrestricted.

\section{EGFP expression in EGFP mRNA electroporated DCs}

To confirm the translation efficiency from introduced mRNA to protein, the mDCs were electroporated with EGFP mRNA. The expression coefficient of EGFP was more than 95\% (Figure 4a). This result indicates that DCs can translate the introduced mRNAs to encoded protein.

\section{Profiles of surface markers of induced DCs}

A comparison of surface marker expression between imDCs and $\mathrm{mDCs}$ was shown (Figure 4c). Twenty nine patients were evaluable. The expression of each antigen in imDCs was found in $17.5 \pm 2.9 \%$ (CD80), $67.1 \pm 3.1 \%$ (CD86), $2.8 \pm 0.7 \%$ (CD83), $92.6 \pm 1.7 \%$ (CD40), $9.5 \pm 2.3 \%$ (CD14), 98.6 $\pm 0.3 \%$ (HLA-ABC) and $92.8 \pm 1.8 \%$ (HLA$\mathrm{DR})$. The expression of each antigen in $\mathrm{mDCs}$ was found in $92.1 \pm 1.5 \%$ (CD80), $96.5 \pm 0.7 \%$ (CD86), $75.6 \pm 3.3 \%$ (CD83), $98.9 \pm 0.5 \%$ (CD40), $4.6 \pm 3.4 \%$ (CD14), 99.4 \pm $0.2 \%$ (HLA-ABC) and $96.6 \pm 1.1 \%$ (HLA-DR). The percentage of CD80+, CD83+, and CD86+ DCs was extremely increased in $\mathrm{mDCs}$ as compared with imDCs $(\mathrm{P}<0.0001)$. A high expression level of $\mathrm{CD} 40$ was also observed in $\mathrm{mDCs}$ $(\mathrm{P}=0.0004)$. HLA-class I and HLA-class II expression levels were identical between imDCs and mDCs.

Change of CD11b + CD33+ cells and CD4+ CD25+ Foxp3+ cells in PBMCs

We assessed negative immune factors focusing on $\mathrm{CD} 11 \mathrm{~b}+\mathrm{CD} 33+$ cells $(\mathrm{n}=14)$ and CD4+ CD25+ Foxp3+ cells $(n=18)$ in PBMCs before and one month after 3 


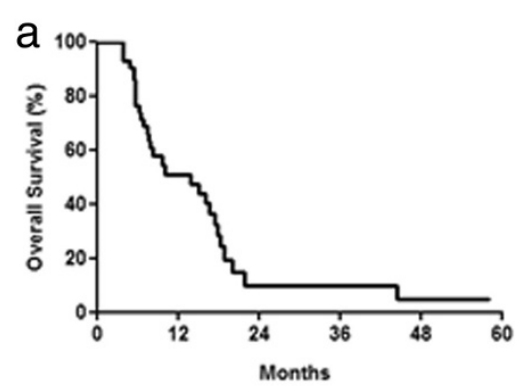

C

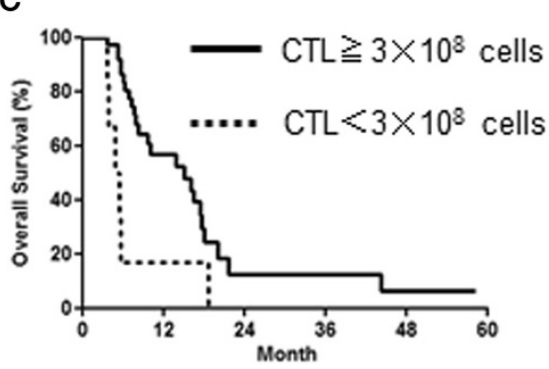

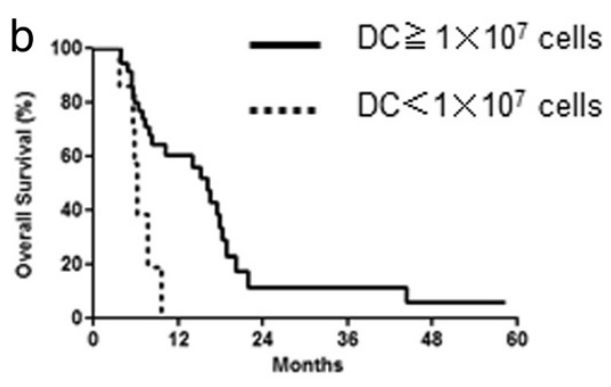

d

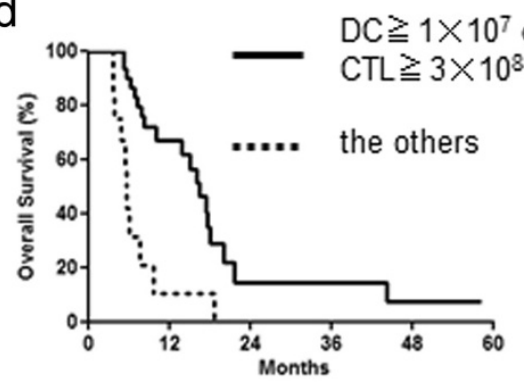

Figure 3 Overall survival rates in patients with advanced pancreatic cancer treated by AIT with MUC1-DCs and MUC1-CTLs plus GEM. a; MST was 13.9 months, and the 1-year survival rate was $51.1 \%$ in all 42 patients. b; 35 patients who received more than $1 \times 10^{7}$ MUC1-DCs per injection (MST, 16.1 months) vs. 7 patients who received less than $1 \times 10^{7}$ cells (MST, 6.2 months), $p=0.0036$. $\mathbf{c} ; 36$ patients who received more than $3 \times 10^{8}$ MUC1-CTLs per injection (MST, 15.1 months) vs. 6 patients who received less than $3 \times 10^{8}$ (MST, 5.2 months), $p=0.0060$. d; 30 patients who received both more than $1 \times 10^{7} \mathrm{MUC1}$-DCs per injection and $3 \times 10^{8}$ MUC1-CTLs per injection (MST, 16.5 months) vs. the other 12 patients (MST, 5.7 months), $p=0.00020$.

transfer. Before treatment there was no difference in the percentage of CD11b + CD33 + cells between patients with $\mathrm{CR}, \mathrm{PR}$, and $\mathrm{SD}(15.1 \pm 2.2, \mathrm{n}=11)$ and patients with $\mathrm{PD}$ $(17.8 \pm 3.9, \mathrm{n}=3)$. After treatment, the percentage of CD11b + CD33+ cells in patients with CR, PR and SD $(10.2 \pm 1.6)$ was significantly lower than patients with PD $(21.9 \pm 4.0)(\mathrm{p}=0.0430)$ (Figure $5 \mathrm{~b})$. Before treatment there was no difference in the percentage of CD4+ CD25+ Foxp3+ cells between patients with CR, PR and SD $(0.68 \pm 0.20, n=14)$ and patients with PD $(1.03 \pm$ $0.62, \mathrm{n}=4)$. After treatment, the percentage of CD4+ CD25+ Foxp3+ cells in patients with CR, PR and SD
$(0.57 \pm 0.18)$ was significantly lower than patients with $\mathrm{PD}(1.33 \pm 0.41)(\mathrm{p}=0.0495)$ (Figure $5 \mathrm{f})$.

\section{ELISPOT analysis}

IFN- $\gamma$ ELISPOT assay was performed to evaluate the specific responses to MUC1 of immune effector cells from 6 patients. The number of MUC1 specific spots was $6.8 \pm$ $2.3,13.1 \pm 5.8$ and $23.2 \pm 13.9$, prior to treatment, after first treatment and after third treatment, respectively. More IFN- $\gamma$ spots were observed in post-treatment compared with pretreatment PBMC samples. Although IFN- $\gamma$ activity was increased in this assay, it was still

Table 2 Patient characteristics between the high dose group and low dose group

\begin{tabular}{|c|c|c|c|c|c|c|}
\hline & \multicolumn{3}{|c|}{$\mathrm{DC}$} & \multicolumn{3}{|c|}{ CTL } \\
\hline & $\begin{array}{l}\text { High dose group } \\
\qquad(\mathrm{n}=35)\end{array}$ & $\begin{array}{l}\text { Low dose group } \\
\qquad(n=7)\end{array}$ & p-value & $\begin{array}{l}\text { High dose group } \\
\qquad(n=36)\end{array}$ & $\begin{array}{l}\text { Low dose group } \\
\qquad(n=6)\end{array}$ & $p$-value \\
\hline Stage & & & $p=0.3053$ & & & $p=0.0976$ \\
\hline III & 12 & 2 & & 14 & 0 & \\
\hline IV & 17 & 2 & & 14 & 5 & \\
\hline Recurrence & 6 & 3 & & 8 & 1 & \\
\hline Liver metastasis (pretreatment) & & & $p=0.5788$ & & & $p=1.000$ \\
\hline Absence & 30 & 5 & & 30 & 5 & \\
\hline Presence & 5 & 2 & & 6 & 1 & \\
\hline
\end{tabular}

DC; dendritic cell, CTL; cytotoxic T lymphocyte. 
Table 3 Comparison between the clinically good and poor responders

\begin{tabular}{|c|c|c|c|}
\hline Characteristics & Clinically good (CR/PR/SD) & Clinically poor (PD) & p-value \\
\hline Number of patients & 26 & 16 & \\
\hline Age (years) & $61.6(37-81)$ & $65.6(43-81)$ & $p=0.2434$ \\
\hline Sex & & & $p=0.7513$ \\
\hline Males & 12 & 9 & \\
\hline Females & 14 & 7 & \\
\hline Stage & & & $p=0.0735$ \\
\hline III & 12 & 2 & \\
\hline IV & 9 & 10 & \\
\hline Recurrence & 5 & 4 & \\
\hline Liver metastasis (pretreatment) & & & $p=0.0081$ \\
\hline Absence & 25 & 10 & \\
\hline Presence & 1 & 6 & \\
\hline NLR & $2.3(0.7-6.4)$ & $3.1(0.4-6.1)$ & $p=0.1364$ \\
\hline Number of CTLs ( $\times 10^{8} /$ time) & $7.0(2.8-12.4)$ & $5.1(1.0-9.0)$ & $p=0.0537$ \\
\hline Number of DCs (x107/time) & $2.1(0.9-3.9)$ & $1.2(0.04-2.9)$ & $p=0.0015$ \\
\hline
\end{tabular}

CR; complete response, PR; partial response, SD; stable disease, PD; progressive disease NLR; neutrophil/lymphocyte ratio, CTL; cytotoxic T lymphocyte,

DC; dendritic cell.

unclear which cells had high activity such as CTL or NK cells (Figure 6).

Monitoring of in vivo migration of ${ }^{111}$ Indium (In)-oxine labeled dendritic cells with scintigraphy

Scintigraphic images obtained from one patient $2 \mathrm{~h}$ and $48 \mathrm{~h}$ after DC administration demonstrated that ${ }^{111}$ In-oxine labeled DCs accumulated at the injection site and regional lymph nodes $2 \mathrm{~h}$ after injection. Forty-eight hours after injection, the accumulation extended into distant lymph nodes, but still remained in the injection site and regional lymph node (Figure $2 \mathrm{e}$ and $\mathrm{f}$ ).

\section{Table 4 Grade 3 and 4 Adverse Events in $\mathbf{4 2}$ patients}

\begin{tabular}{ccc}
\hline Adverse event & Number of patients & $\%$ \\
\hline Leukocytes & 11 & 26.2 \\
Neutrophils & 13 & 31 \\
Platelets & 1 & 2.4 \\
Hemoglobin & 5 & 11.9 \\
AST & 1 & 2.4 \\
ALT & 1 & 2.4 \\
Fatigue & 5 & 11.9 \\
Anorexia & 6 & 14.3 \\
Diarrhea & 3 & 7.1 \\
Mucositis/stomatitis & 1 & 2.4 \\
Nausea & 3 & 7.1 \\
Vomiting & 1 & 2.4 \\
\hline AST; aspata
\end{tabular}

AST; aspartate aminotransferase, ALT; alanine aminotransferase.

\section{Discussion}

In the present study, adoptive immunotherapy (AIT) with MUC1-DCs and MUC1-CTLs plus GEM resulted in a 1-year survival rate of greater than $50 \%$ in patients with unresectable or recurrent pancreatic invasive ductal carcinoma (Figure 3a). One patient, who had liver metastasis after curative surgery, had CR (Figure 2a to d). Three patients had PR, and one of these patients had curative surgery 12 months after this therapy. Although it have been reported that $73 \%$ of patients who died from pancreatic cancer were found to present with liver metastases at autopsy [31], in this therapy liver metastasis appeared in only 5 patients (14\%) among 35 patients without liver metastasis before treatment. We observed no severe adverse events related to our AIT (Table 4).

MST following GEM monotherapy, which is the standard chemotherapy for unresectable pancreatic cancer, was 5.7 months, and the 1-year survival rate was 18\% [24]. Although some trials of combination therapies including GEM and other cytotoxic agents resulted in improved response rates over GEM alone, they failed to show survival benefits [32-34]. The combination of erlotinib plus GEM showed a significant improvement in overall survival; however, the increase in MST was marginal (6.24 vs. 5.91 months) [35]. In another study, MST was 11.1 months for the FOLFIRINOX group, compared with 6.8 months in the GEM group, showing a significant difference. However, markedly more adverse events were noted in the FOLFIRINOX group [36]. Since these outcomes in advanced pancreatic cancer are still poor, more effective treatment strategies are required. 

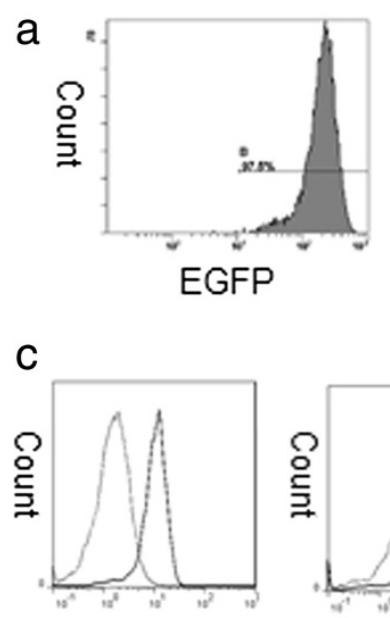

$\operatorname{CD} 80$

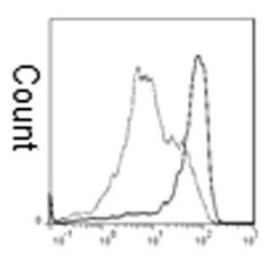

CD86
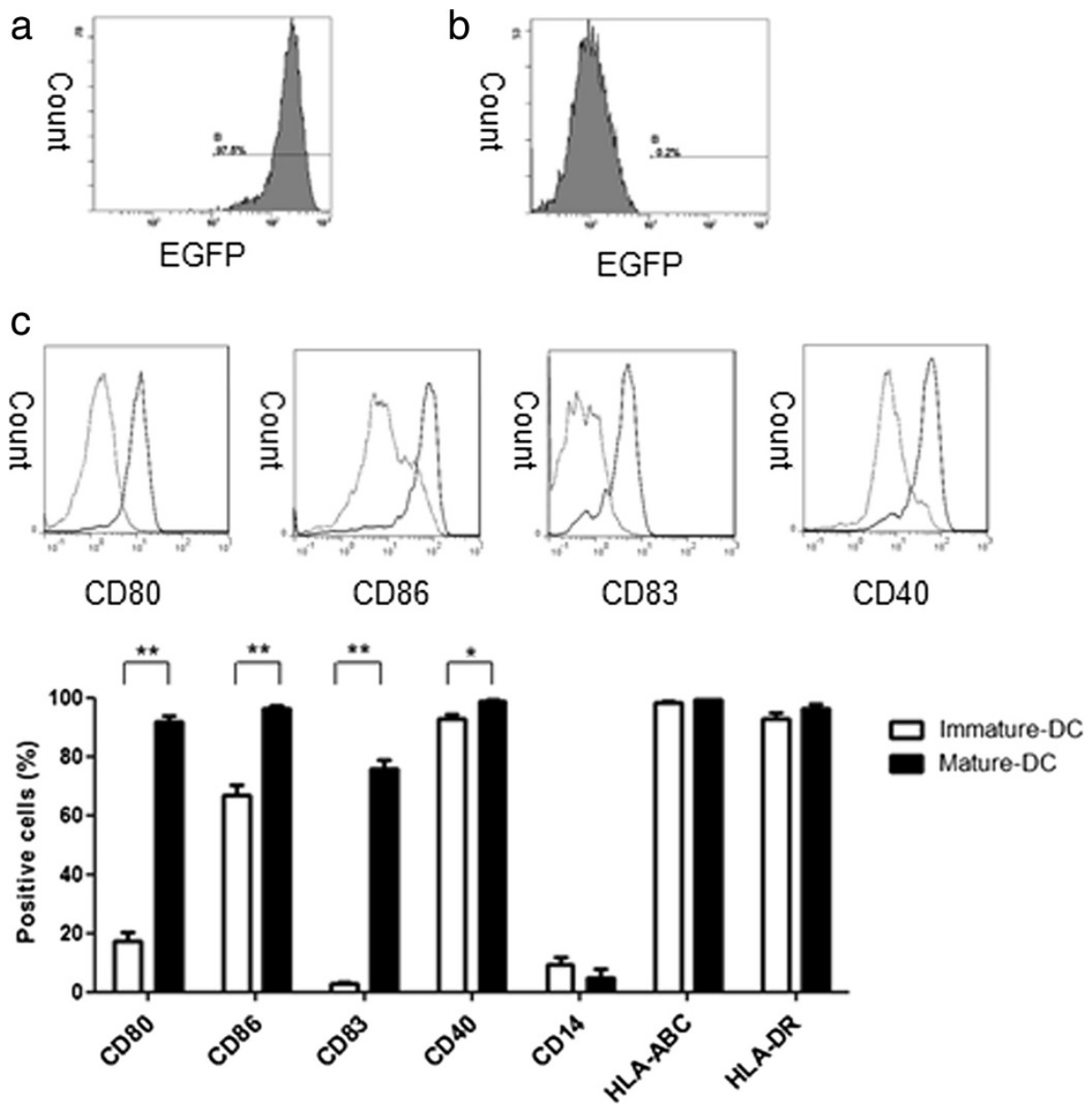

Figure 4 Flow cytometric analysis of DCs. EGFP expression was analyzed by flow cytometry $18 \mathrm{~h}$ post-transfection. a; The expression level of EGFP was more than 95\%. b; As a control non-transfected DC were used. c; Expression of DC surface markers was evaluated by flow cytometry. Twenty nine patients were evaluable. Comparative data were shown in histograms for immature (dotted line) and mature (solid line) DCs. The expression of each antigen in imDCs was found in 17.5 \pm 2.9\% (CD80), $67.1 \pm 3.1 \%$ (CD86), $2.8 \pm 0.7 \%$ (CD83), 92.6 $\pm 1.7 \%$ (CD40), 9.5 $\pm 2.3 \%$ (CD14), $98.6 \pm 0.3 \%$ (HLA-ABC) and $92.8 \pm 1.8 \%$ (HLA-DR). The expression of each antigen in mDCs was found in $92.1 \pm 1.5 \%$ (CD80), 96.5 $\pm 0.7 \%(C D 86)$, $75.6 \pm 3.3 \%$ (CD83), $98.9 \pm 0.5 \%$ (CD40), $4.6 \pm 3.4 \%$ (CD14), $99.4 \pm 0.2 \%$ (HLA-ABC) and $96.6 \pm 1.1 \%$ (HLA-DR). ${ }^{*} p=0.0004,{ }^{* *} p<0.0001$.

We have previously used DCs pulsed with MUC1 peptide [16]. In this study, mDCs were transfected with MUC1-mRNA by electroporation, because antigen epitopes are naturally processed, and a variety of different epitopes are long term presented by both HLA class I and class II molecules. It has been reported the advantage of endogenous expression by $\mathrm{DC}$ is that $\mathrm{T}$ cell epitopes do not need to be specified, HLA type is not a limiting factor and multiple epitopes (both CTL and helper T cell epitopes) can be presented [37]. In our previous therapy (MUC1 peptide-pulsed DCs and MUC1-CTLs), the MST was 9.8 months [16]; in the present study, the MST was 13.9 months. The improved survival benefit of the present study may be related to patient characteristics such as distant metastasis, the GEM combination, or MUC1 mRNA transfection. Distant metastasis such as liver metastasis, lung metastasis or peritoneal dissemination was present in
15 of $20(75 \%)$ previous patients and 28 of $42(66.7 \%)$ present patients, which is no significant difference.

GEM has the potential to augment the antitumor effects of cancer immunotherapy by suppressing Treg induction [25,38], and also reduces MDSC [39], but does not reduce CD4+ T cells, CD8+ T cells, NK cells, macrophages, or B cells [40]. We therefore performed a combination therapy with AIT and GEM. In the present study, we observed a significant decrease in the percentages of MDSC (Figure 5b, $\mathrm{p}=0.043$ ) and Treg (Figure 5f, $\mathrm{p}=0.0495$ ) in patients with CR, PR and SD when compared with those in patients with PD. Hence, we speculated that clinical benefit may be related to the reductions of MDSC and Treg.

A survival and clinical benefit was shown in the patients who received high dose MUC1-DCs and MUC1-CTLs per injection (Figure $2 \mathrm{~b}$ to $3 \mathrm{~d}$, Table 3 ). Administration of 

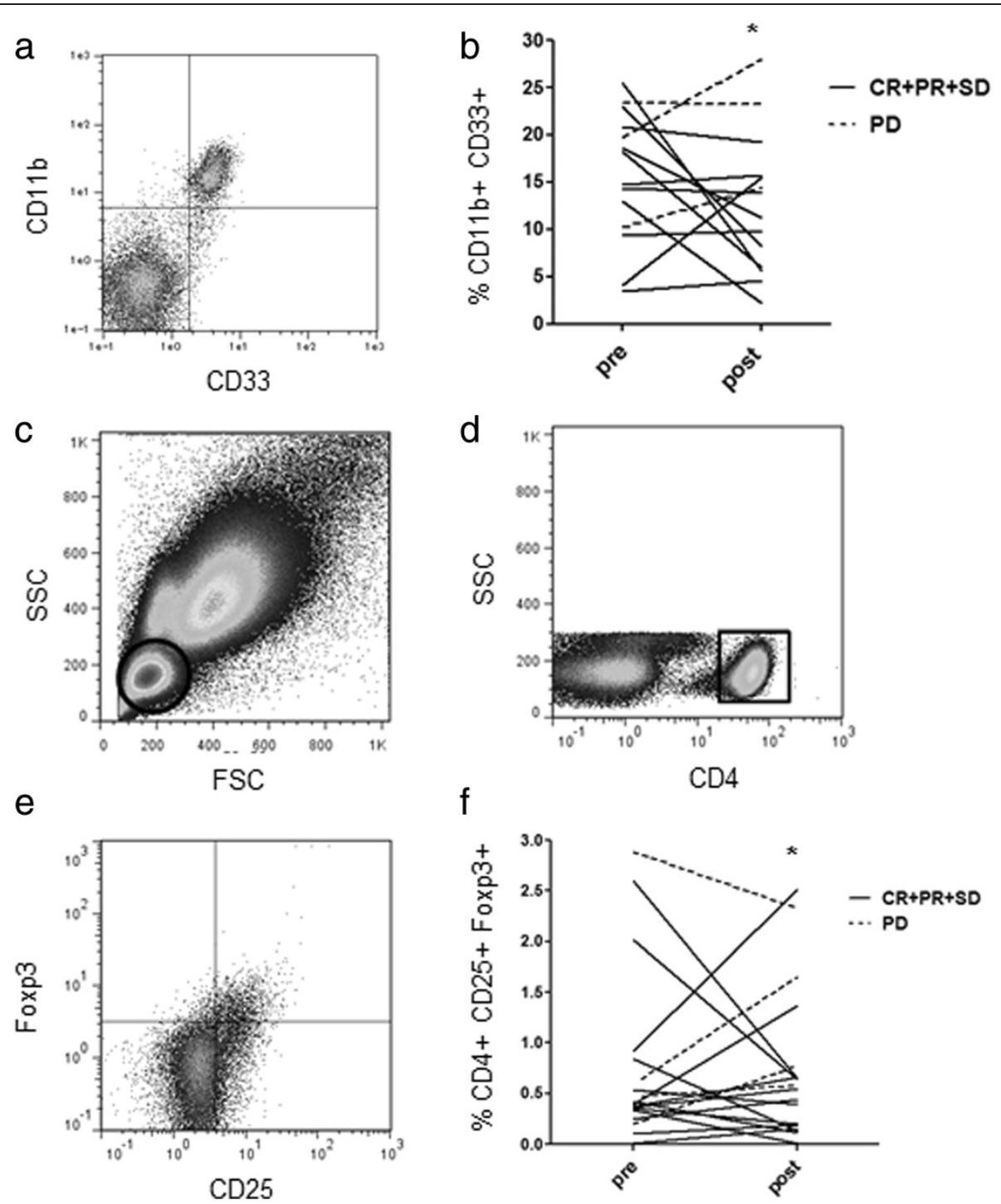

Figure 5 Frequency of $C D 11 b+C D 33+$ cells and CD4 + CD25 + Foxp3+ cells in the PBMCs. a; Analysis for CD11b as well as CD33 expression by flow cytometry. $\mathbf{b}$; The percentage of CD11b + CD33+ cells of patients with CR, PR and SD ( $n=11)$ (solid line) and PD ( $n=3$ ) (dashed line) was measured. ${ }^{*} p=0.043$. c ; Lymphocytes were identified based on their characteristic properties shown in the FSC and SSC. $\mathbf{d}$; A representative gating was set for CD4+ cells from lymphocytes. e; Analysis for CD25 as well as Foxp3 expression in the CD4+ lymphocytes gate. f; The percentage of CD4 + CD25 + Foxp3+ cells of patients with CR, PR and SD $(n=14)$ (solid line) and PD $(n=4)$ (dashed line) was measured. * $p=0.0495$.

a large number of DCs and CTLs may be necessary to achieve a clinical effect. Induction of CTLs in patients with advanced pancreatic cancer may be suppressed by activated granulocytes and MDSC [41]. We have reported that pancreatic cancer patients had low CTL precursors reactive to EBV peptide as compared with healthy volunteers [4]. This result suggests that the cellular immunity of these patients might be depressed, and therefore other supportive immunotherapies may be needed for these patients to increase their general level of immunity prior to specific immunotherapy.

The migration of $\mathrm{DC}$ is an important question that needs to be addressed in clinical therapy. A key step involved with $\mathrm{T}$ cell sensitization after administration is DC migration into regional draining lymph nodes and antigen presentation to lymphocytes. In the present study, the induction of mDCs was performed successfully, which was demonstrated by the high expression of CD83 (75.6 \pm $3.3 \%$, Figure $4 \mathrm{c}$ ) that expressed at activated and $\mathrm{mDCs}$ [42]. It has been reported that a better migration activity is obtained using intradermal route than subcutaneous routes and that $\mathrm{mDCs}$ show higher migration than imDCs $[43,44]$. We confirmed the migration of administered mDCs by scintigraphic images collected 2 and $48 \mathrm{~h}$ after injection in one patient. Two hours after injection, $\mathrm{mDCs}$ migrated from the injection site to inguinal lymph nodes. 


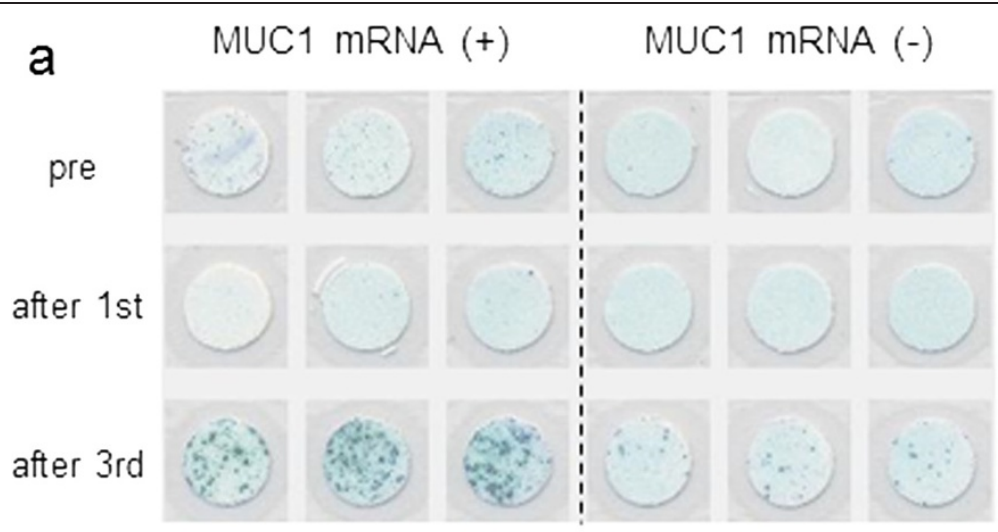

b

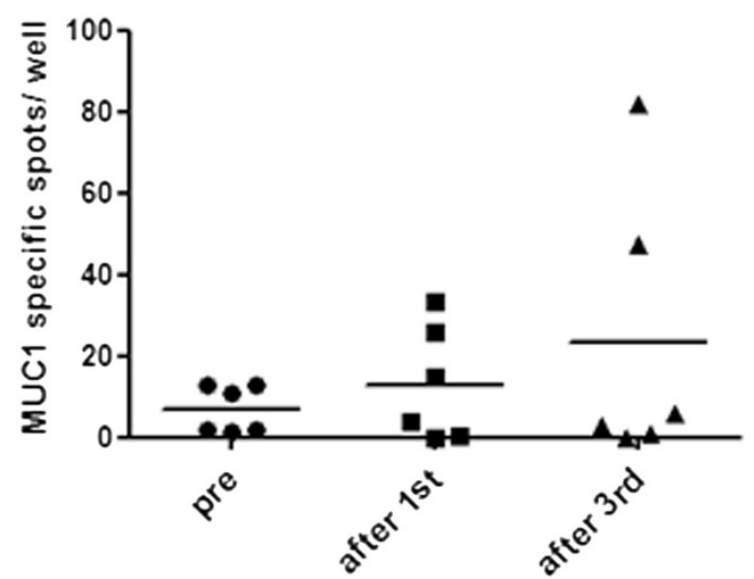

Figure 6 Representative immunologic monitoring assays detecting antigen-specific responses induced IFN- $\gamma$ producing cells. a; IFN- $\gamma$ producing cells were increased in PBMCs co-cultured with PBMCs electroporated with MUC1 mRNA compared with PBMCs co-cultured with PBMCs electroporated without MUC1 mRNA. $\mathbf{b}$; Six patients were evaluable. More MUC1 specific spots were observed in post-treatment compared with pretreatment PBMC samples.

Forty-eight hours after injection, that accumulation extended into distant lymph node, but still remained in the injection site as well as inguinal lymph nodes (Figure $2 \mathrm{e}$ and $\mathrm{f}$ ).

In conclusion, our cancer immunotherapy in combination with GEM was safe and appears to be effective for the patients with unresectable pancreatic cancer. Although we need to verify this preliminary result by a much larger prospective randomized study, we believe that these findings surely lead to the novel therapeutic strategy for advanced pancreatic cancer.

\section{Conclusions}

We retrospectively analyzed the outcome of 42 patients with unresectable or recurrent pancreatic cancer treated with MUC1-DCs (MUC1-mRNA transfected DCs) and MUC1-CTLs (lymphocytes stimulated by co-culture with a MUC1 expressing human pancreatic cancer cell line and IL-2). Our adoptive immunotherapy was safe and effective in a subgroup with sufficient induction of DCs and CTLs. Further randomized control studies of large numbers of patients are needed to confirm the efficacy of this combination therapy for unresectable pancreatic cancer.

\section{Additional file}

Additional file 1: Figure S1. Cytotoxicity of induced MUC1-CTLs and
antibody inhibition of cytotoxicity. (a) CTLs were stimulated by the
MUC1-expressing human pancreatic cancer cell line, YPK-1 (HLA-A 2402,
MUC1-positive). Target cell lines were YPK-1, YPK-3 (pancreatic cancer,
HLA-A 0201, MUC1-positive), YES-2 (esophageal cancer, HLA-A 2404,
MUC1-negative) and YES-1 (esophageal cancer, HLA-A 0201, MUC1-negative).
Induced CTLs were cytotoxic against MUC1-expressing pancreatic cancer
cell lines regardless of the HLA-A phenotype. Low cytotoxicity was observed
in MUC1-negative esophageal cancer cell lines. Cytotoxicity was MHC
unrestricted and clearly decreased with the decreasing effector cell number.
(b) Anti-CD3 or -CD8 mAb strongly inhibited cytotoxicity against YPK-1cells,
whereas anti-class I mAb showed no inhibition. YPK-1 cells treated with
anti-MUC1 mAb also showed a low cytotoxicity.

\section{Abbreviations}

AIT: Adoptive immunotherapy; CR: Complete response; CT: Computed tomography; CTCAE: Common Terminology Criteria for Adverse Events; CTLs: Cytotoxic T lymphocytes; DCs: Dendritic cells; ECOG: Eastern Cooperative Oncology Group; EGFP: Enhanced green fluorescent protein; ELISPOT: Enzyme-Linked ImmunoSpot; FSC: Forward scatter; Gd-EOB-DTPA: Gadolinium 
ethoxybenzyl diethylenetriamine pentaacetic acid; GEM: Gemcitabine; GM-CSF: Granulocyte macrophage colony-stimulating factor; HLA: Human leukocyte antigen; IFN- : Interferon- $\gamma$; IL-2: Interleukin 2; imDC: Immature DCs; ${ }^{111}$ In-Oxine: Indium oxine; LAK: Lymphokine-activated killer; mAbs: Monoclonal antibodies; mDCs: Mature DCs; MDSC: Myeloid-derived suppressor cell; MRI: Magnetic resonance imaging; MST: Median survival time; MUC1: Mucin 1; PBMCs: Peripheral blood mononuclear cells; PD: Progressive disease; PR: Partial response; PS: Performance status; RECIST: Response evaluation criteria in solid tumors; SD: Stable disease; SE: Standard error; SSC: Side scatter; TNF-a: Tumor necrosis factor-a; Treg: Regulatory T cell; U: Units.

\section{Competing interests}

The authors declare that they have no competing interests.

\section{Authors' contributions}

YS performed and evaluated the study, and wrote the manuscript. SH designed this clinical study and participated in review and revision of the manuscript. YM, HM, MI, NS, KY, TU, SY, KS, YS, TY and YH assisted to perform the study and data analysis. MO participated as principle investigator of the study, and drafted the manuscript. All authors read and approved the final manuscript.

\section{Acknowledgments}

The authors thank Ms. Akiko Sano and Ms. Kaori Kaneyasu for their excellent technical assistance with this work. This work was supported by JSPS KAKENHI Grant Number 24390317. This study was also performed as a research program of the Project for Development of Innovative Research on Cancer Therapeutics (P-Direct), Ministry of Education, Culture, Sports, Science and Technology of Japan.

\section{Author details}

'Department of Digestive Surgery and Surgical Oncology (Department of Surgery II), Yamaguchi University Graduate School of Medicine, 1-1-1 Minami-kogushi, Ube, Yamaguchi 755-8505, Japan. ${ }^{2}$ Department of Oncology and Laboratory Medicine, Yamaguchi University School of Medicine, 1-1- 1 Minami-Kogushi, Ube, Yamaguchi 755-8505, Japan.

Received: 23 February 2014 Accepted: 12 June 2014

Published: 19 June 2014

\section{References}

1. Jemal A, Siegel R, Xu J, Ward E: Cancer statistics, 2010. CA Cancer J Clin 2010, 60:277-300.

2. Friess H, Gassmann M, Buchler MW: Adjuvant therapy of pancreatic cancer using monoclonal antibodies and immune response modifiers. Int $J$ Pancreatol 1997, 21:43-52.

3. Hersh EM, Metch BS, Muggia FM, Brown TD, Whitehead RP, Budd GT, Rinehart JJ, Crawford ED, Bonnet JD, Behrens BC: Phase II studies of recombinant human tumor necrosis factor alpha in patients with malignant disease: a summary of the Southwest Oncology Group experience. J Immunother (1991) 1991, 10:426-431.

4. Suzuki N, Maeda Y, Tanaka S, Hida N, Mine T, Yamamoto K, Oka M, Itoh K: Detection of peptide-specific cytotoxic T-lymphocyte precursors used for specific immunotherapy of pancreatic cancer. Int J Cancer 2002, 98:45-50.

5. Sparano JA, Fisher RI, Weiss GR, Margolin K, Aronson FR, Hawkins MJ, Atkins MB, Dutcher JP, Gaynor ER, Boldt DH, Doroshow JH, Ernest ML, Sznol M, Mier JW: Phase II trials of high-dose interleukin-2 and lymphokine-activated killer cells in advanced breast carcinoma and carcinoma of the lung, ovary, and pancreas and other tumors. I Immunother Emphasis Tumor Immunol 1994, 16:216-223.

6. Petersen TR, Dickgreber N, Hermans IF: Tumor antigen presentation by dendritic cells. Crit Rev Immunol 2010, 30:345-386.

7. Griffioen M, Borghi M, Schrier PI, Osanto S, Schadendorf D: Analysis of T-cell responses in metastatic melanoma patients vaccinated with dendritic cells pulsed with tumor lysates. Cancer Immunol Immunother 2004, 53:715-722.

8. Rains N, Cannan RJ, Chen W, Stubbs RS: Development of a dendritic cell (DC)-based vaccine for patients with advanced colorectal cancer. Hepatogastroenterology 2001, 48:347-351.

9. Lepisto AJ, Moser AJ, Zeh H, Lee K, Bartlett D, McKolanis JR, Geller BA, Schmotzer A, Potter DP, Whiteside T, Finn OJ, Ramanathan RK: A phase I/II study of a MUC1 peptide pulsed autologous dendritic cell vaccine as adjuvant therapy in patients with resected pancreatic and biliary tumors. Cancer Ther 2008, 6:955-964.

10. Gendler SJ, Lancaster CA, Taylor-Papadimitriou J, Duhig T, Peat N, Burchell J, Pemberton L, Lalani EN, Wilson D: Molecular cloning and expression of human tumor-associated polymorphic epithelial mucin. J Biol Chem 1990, 265:15286-15293.

11. Masaki Y, Oka M, Ogura Y, Ueno T, Nishihara K, Tangoku A, Takahashi M, Yamamoto M, Irimura T: Sialylated MUC1 mucin expression in normal pancreas, benign pancreatic lesions, and pancreatic ductal adenocarcinoma. Hepatogastroenterology 1999, 46:2240-2245.

12. Barnd DL, Lan MS, Metzgar RS, Finn OJ: Specific, major histocompatibility complex-unrestricted recognition of tumor-associated mucins by human cytotoxic T cells. Proc Natl Acad Sci U S A 1989, 86:7159-7163.

13. Jerome KR, Barnd DL, Bendt KM, Boyer CM, Taylor-Papadimitriou J, McKenzie IF, Bast RC Jr, Finn OJ: Cytotoxic T-lymphocytes derived from patients with breast adenocarcinoma recognize an epitope present on the protein core of a mucin molecule preferentially expressed by malignant cells. Cancer Res 1991, 51:2908-2916.

14. Ioannides CG, Fisk B, Jerome KR, Irimura T, Wharton JT, Finn OJ: Cytotoxic T cells from ovarian malignant tumors can recognize polymorphic epithelial mucin core peptides. J Immunol 1993, 151:3693-3703.

15. Kawaoka T, Oka M, Takashima M, Ueno T, Yamamoto K, Yahara N, Yoshino S, Hazama S: Adoptive immunotherapy for pancreatic cancer: cytotoxic $T$ lymphocytes stimulated by the MUC1-expressing human pancreatic cancer cell line YPK-1. Oncol Rep 2008, 20:155-163.

16. Kondo H, Hazama S, Kawaoka T, Yoshino S, Yoshida S, Tokuno K, Takashima $M$, Ueno T, Hinoda $Y$, Oka M: Adoptive immunotherapy for pancreatic cancer using MUC1 peptide-pulsed dendritic cells and activated T lymphocytes. Anticancer Res 2008, 28:379-387.

17. Palucka K, Banchereau J: Cancer immunotherapy via dendritic cells. Nat Rev Cancer 2012, 12:265-277.

18. Nonn M, Schinz M, Zumbach K, Pawlita M, Schneider A, Durst M, Kaufmann AM: Dendritic cell-based tumor vaccine for cervical cancer I: in vitro stimulation with recombinant protein-pulsed dendritic cells induces specific T cells to HPV16 E7 or HPV18 E7. J Cancer Res Clin Oncol 2003, 129:511-520.

19. Katano M, Morisaki T, Koga K, Nakamura M, Onishi H, Matsumoto K, Tasaki A, Nakashima H, Akiyoshi T, Nakamura M: Combination therapy with tumor cell-pulsed dendritic cells and activated lymphocytes for patients with disseminated carcinomas. Anticancer Res 2005, 25:3771-3776.

20. Strobel I, Berchtold S, Gotze A, Schulze U, Schuler G, Steinkasserer A: Human dendritic cells transfected with either RNA or DNA encoding influenza matrix protein $\mathrm{M} 1$ differ in their ability to stimulate cytotoxic $\mathrm{T}$ lymphocytes. Gene Ther 2000, 7:2028-2035.

21. Abdulhaqq SA, Weiner DB: DNA vaccines: developing new strategies to enhance immune responses. Immunol Res 2008, 42:219-232.

22. Ochoa-Callejero L, Berraondo P, Crettaz J, Olague C, Vales A, Ruiz J, Prieto J, Tennant BC, Menne S, Gonzalez-Aseguinolaza G: Woodchuck dendritic cells generated from peripheral blood mononuclear cells and transduced with recombinant human adenovirus serotype 5 induce antigen-specific cellular immune responses. J Med Virol 2007, 79:522-529.

23. Yu Z, Sun H, Zhang T, Yang T, Long H, Ma B: Specific antitumor effects of tumor vaccine produced by autologous dendritic cells transfected with allogeneic osteosarcoma total RNA through electroporation in rats. Cancer Biol Ther 2009, 8:973-980.

24. Burris HA 3rd, Moore MJ, Andersen J, Green MR, Rothenberg ML, Modiano MR, Cripps MC, Portenoy RK, Storniolo AM, Tarassoff P, Nelson R, Dorr FA, Stephens CD, Von Hoff DD: Improvements in survival and clinical benefit with gemcitabine as first-line therapy for patients with advanced pancreas cancer: a randomized trial. J Clin Oncol 1997, 15:2403-2413.

25. Kan S, Hazama S, Maeda K, Inoue Y, Homma S, Koido S, Okamoto M, Oka M: Suppressive effects of cyclophosphamide and gemcitabine on regulatory T-cell induction in vitro. Anticancer Res 2012, 32:5363-5369.

26. Dauer M, Herten J, Bauer C, Renner F, Schad K, Schnurr M, Endres S, Eigler A: Chemosensitization of pancreatic carcinoma cells to enhance $T$ cell-mediated cytotoxicity induced by tumor lysate-pulsed dendritic cells. J Immunother 2005, 28:332-342.

27. Bauer C, Bauernfeind F, Sterzik A, Orban M, Schnurr M, Lehr HA, Endres S, Eigler A, Dauer M: Dendritic cell-based vaccination combined with gemcitabine increases survival in a murine pancreatic carcinoma model. Gut 2007, 56:1275-1282. 
28. Trotti A, Colevas AD, Setser A, Rusch V, Jaques D, Budach V, Langer C, Murphy B, Cumberlin R, Coleman CN, Rubin P: CTCAE v3.0: development of a comprehensive grading system for the adverse effects of cancer treatment. Semin Radiat Oncol 2003, 13:176-181.

29. Therasse P, Arbuck SG, Eisenhauer EA, Wanders J, Kaplan RS, Rubinstein L, Verweij J, Van Glabbeke M, van Oosterom AT, Christian MC, Gwyther SG: New guidelines to evaluate the response to treatment in solid tumors. European Organization for Research and Treatment of Cancer, National Cancer Institute of the United States, National Cancer Institute of Canada. J Natl Cancer Inst 2000, 92:205-216.

30. Mace TA, Ameen Z, Collins A, Wojcik S, Mair M, Young GS, Fuchs JR, Eubank TD, Frankel WL, Bekaii-Saab T, Bloomston M, Lesinski GB: Pancreatic cancer-associated stellate cells promote differentiation of myeloid-derived suppressor cells in a STAT3-dependent manner. Cancer Res 2013, 73:3007-3018.

31. Foster JH, Lundy J: Liver metastases. Curr Prob/ Surg 1981, 18:157-202.

32. Louvet $C$, Labianca R, Hammel P, Lledo G, Zampino MG, Andre T, Zaniboni A, Ducreux M, Aitini E, Taieb J, Faroux R, Lepere C, de Gramont A, Gercor G: Gemcitabine in combination with oxaliplatin compared with gemcitabine alone in locally advanced or metastatic pancreatic cancer: results of a GERCOR and GISCAD phase III trial. J Clin Oncol 2005, 23:3509-3516.

33. Philip PA, Benedetti J, Corless CL, Wong R, O'Reilly EM, Flynn PJ, Rowland KM, Atkins JN, Mirtsching BC, Rivkin SE, Khorana AA, Goldman B, Fenoglio-Preiser $C M$, Abbruzzese JL, Blanke CD: Phase III study comparing gemcitabine plus cetuximab versus gemcitabine in patients with advanced pancreatic adenocarcinoma: Southwest Oncology Group-directed intergroup trial S0205. J Clin Oncol 2010, 28:3605-3610.

34. Ueno H, loka T, Ikeda M, Ohkawa S, Yanagimoto H, Boku N, Fukutomi A, Sugimori K, Baba H, Yamao K, Shimamura T, Sho M, Kitano M, Cheng AL, Mizumoto K, Chen JS, Furuse J, Funakoshi A, Hatori T, Yamaguchi T, Egawa S, Sato A, Ohashi Y, Okusaka T, Tanaka M: Randomized phase III study of gemcitabine plus S-1, S-1 alone, or gemcitabine alone in patients with locally advanced and metastatic pancreatic cancer in Japan and Taiwan: GEST study. J Clin Oncol 2013, 31:1640-1648.

35. Moore MJ, Goldstein D, Hamm J, Figer A, Hecht JR, Gallinger S, Au HJ, Murawa P, Walde D, Wolff RA, Campos D, Lim R, Ding K, Clark G, Voskoglou-Nomikos T, Ptasynski M, Parulekar W, National Cancer Institute of Canada Clinical Trials G: Erlotinib plus gemcitabine compared with gemcitabine alone in patients with advanced pancreatic cancer: a phase III trial of the National Cancer Institute of Canada Clinical Trials Group. J Clin Oncol 2007, 25:1960-1966.

36. Conroy $T$, Desseigne F, Ychou M, Bouche O, Guimbaud R, Becouarn $Y$, Adenis A, Raoul JL, Gourgou-Bourgade S, de la Fouchardiere C, Bennouna J, Bachet JB, Khemissa-Akouz F, Pere-Verge D, Delbaldo C, Assenat E, Chauffert B, Michel P, Montoto-Grillot C, Ducreux M, Groupe Tumeurs Digestives of U, Intergroup P: FOLFIRINOX versus gemcitabine for metastatic pancreatic cancer. N Engl J Med 2011, 364:1817-1825.

37. Schuurhuis DH, Lesterhuis WJ, Kramer M, Looman MG, van Hout-Kuijer M, Schreibelt G, Boullart AC, Aarntzen EH, Benitez-Ribas D, Figdor CG, Punt CJ, de Vries IJ, Adema GJ: Polyinosinic polycytidylic acid prevents efficient antigen expression after mRNA electroporation of clinical grade dendritic cells. Cancer Immunol Immunother 2009, 58:1109-1115.

38. Rettig L, Seidenberg S, Parvanova I, Samaras P, Curioni A, Knuth A, Pascolo $S:$ Gemcitabine depletes regulatory T-cells in human and mice and enhances triggering of vaccine-specific cytotoxic T-cells. Int J Cancer 2011, 129:832-838.

39. Sinha P, Clements VK, Bunt SK, Albelda SM, Ostrand-Rosenberg S: Cross-talk between myeloid-derived suppressor cells and macrophages subverts tumor immunity toward a type 2 response. J Immunol 2007, 179:977-983.

40. Suzuki E, Kapoor V, Jassar AS, Kaiser LR, Albelda SM: Gemcitabine selectively eliminates splenic Gr-1+/CD11b + myeloid suppressor cells in tumor-bearing animals and enhances antitumor immune activity. Clin Cancer Res 2005, 11:6713-6721.

41. Finn OJ: Cancer immunology. N Engl J Med 2008, 358:2704-2715.

42. Koga $T$, Duan $H$, Moroi $Y$, Urabe $K$, Furue M: Activated and mature CD83-positive dendritic cells and interferon-gamma-positive cells in skin eruptions of secondary syphilis. Acta Derm Venereol 2003, 83:214-217.
43. Morse MA, Coleman RE, Akabani G, Niehaus N, Coleman D, Lyerly HK: Migration of human dendritic cells after injection in patients with metastatic malignancies. Cancer Res 1999, 59:56-58.

44. Ridolfi R, Riccobon A, Galassi R, Giorgetti G, Petrini M, Fiammenghi L, Stefanelli M, Ridolfi L, Moretti A, Migliori G, Fiorentini G: Evaluation of in vivo labelled dendritic cell migration in cancer patients. J Trans/ Med 2004, 2:27.

doi:10.1186/1479-5876-12-175

Cite this article as: Shindo et al:: Adoptive immunotherapy with MUC1mRNA transfected dendritic cells and cytotoxic lymphocytes plus gemcitabine for unresectable pancreatic cancer. Journal of Translational Medicine 2014 12:175.

\section{Submit your next manuscript to BioMed Central and take full advantage of:}

- Convenient online submission

- Thorough peer review

- No space constraints or color figure charges

- Immediate publication on acceptance

- Inclusion in PubMed, CAS, Scopus and Google Scholar

- Research which is freely available for redistribution

Submit your manuscript at www.biomedcentral.com/submit
C) BioMed Central 